MINERALOGIA, 43, No 3-4: 155-178 (2012)

DOI: 10.2478/v10002-012-0005-3

www.Mineralogia.pl

MineRALOGICAL SOCIETY OF POLAND

Polskie TOWARZYSTWO MINERALOgICZNE

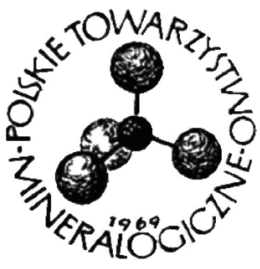

Original paper

\title{
Ore mineralization in the Miedzianka area (Karkonosze-Izera Massif, the Sudetes, Poland): new information
}

\author{
Ksenia MOCHNACKA ${ }^{1}$, Teresa OBERC-DZIEDZIC ${ }^{2}$, Wojciech MAYER ${ }^{1 *}$, \\ Adam PIECZKA ${ }^{1}$ \\ ${ }^{I}$ AGH-University of Science and Technology, Faculty of Geology, Geophysics and Environment Protection, \\ al.Mickiewicza 30,30-059 Kraków,Poland, email:kmoch@geol.agh.edu.pl,wmayer@geol.agh.edu.pl, \\ pieczka@agh.edu.pl \\ ${ }^{2}$ University of Wroctaw, Institute of Geological Sciences, Pl. M. Borna 9, 50-204 Wrocław, Poland, \\ teresa.oberc-dziedzic@ing.uni.wroc.pl \\ *Corresponding author: wmayer@geol.agh.edu.pl
}

Received: 20 July, 2011

Received in revised form: January 15, 2013

Accepted: January 25, 2013

Available online: 28 March, 2013

\begin{abstract}
The Miedzianka mining district has been known for ages as a site of polymetallic ore deposits with copper and, later, uranium as the main commodities. Although recently uneconomic and hardly accessible, the Miedzianka ores attract Earth scientists due to the interesting and still controversial details of their ore structure, mineralogy and origin. Our examination of the ore mineralization from the Miedzianka district was based exclusively on samples collected from old mining dumps located in the vicinity of Miedzianka and Ciechanowice, and on samples from the only available outcrop in Przybkowice. In samples from the Miedzianka field, chalcopyrite, pyrite, galena, bornite, chalcocite, digenite, arsenopyrite, magnetite, sphalerite, tetrahedrite-tennantite, bornite, hematite, martite, pyrrhotite, ilmenite, cassiterite and covellite are hosted in quartz-mica schists and in coarse-grained quartz with chlorite. In the Ciechanowice field, the ore mineralization occurs mainly in strongly chloritized amphibolites occasionally intergrown with quartz and, rarely, with carbonates. Other host-rocks are quartz-chlorite schist and quartzites. Microscopic examination revealed the presence of chalcopyrite, pyrite, sphalerite, galena, tetrahedrite-tennantite, bismuthinite, native $\mathrm{Bi}$, arsenopyrite, löllingite, cassiterite, cobaltite, gersdorffite, chalcocite, cassiterite, bornite, covellite, marcasite and pyrrhotite. Moreover, mawsonite and wittichenite were identified for the first time in the district. In barite veins cross-cutting the greenstones and greenschists in Przybkowice, we found previously-known chalcopyrite, chalcocite and galena. The composition of the hydrothermal fluids is
\end{abstract}


suggested to evolved through a series of consecutive systems characterized, in turn, by Ti-Fe-Sn, Fe$\mathrm{As}-\mathrm{S}, \mathrm{Fe}-\mathrm{Co}-\mathrm{As}-\mathrm{S}, \mathrm{Cu}-\mathrm{Zn}-\mathrm{S}$ and, finally, $\mathrm{Cu}-\mathrm{Pb}-\mathrm{Sb}-\mathrm{As}-\mathrm{Bi}$ compositions.

Key-words: Miedzianka, Ciechanowice, Przybkowice, Karkonosze-Izera Massif, ore deposits, mineral succession, geothermometry

\section{Introduction}

The hydrothermal, vein-type copper-uranium-polymetallic ore deposit of the Miedzianka district is located in the eastern part of the Karkonosze-Izera Massif (KIM), close to the IntraSudetic Fault (Fig.1; Mazur, Aleksandrowski 2001). The bulk of ore mineralization is located near the contact of the Czarnów Schist Formation (Teisseyre 1973) with the Karkonosze granite, but some underground workings in the easternmost part of the mining district were cut in rocks of the Leszczyniec Unit (Mazur, Aleksandrowski 2001).

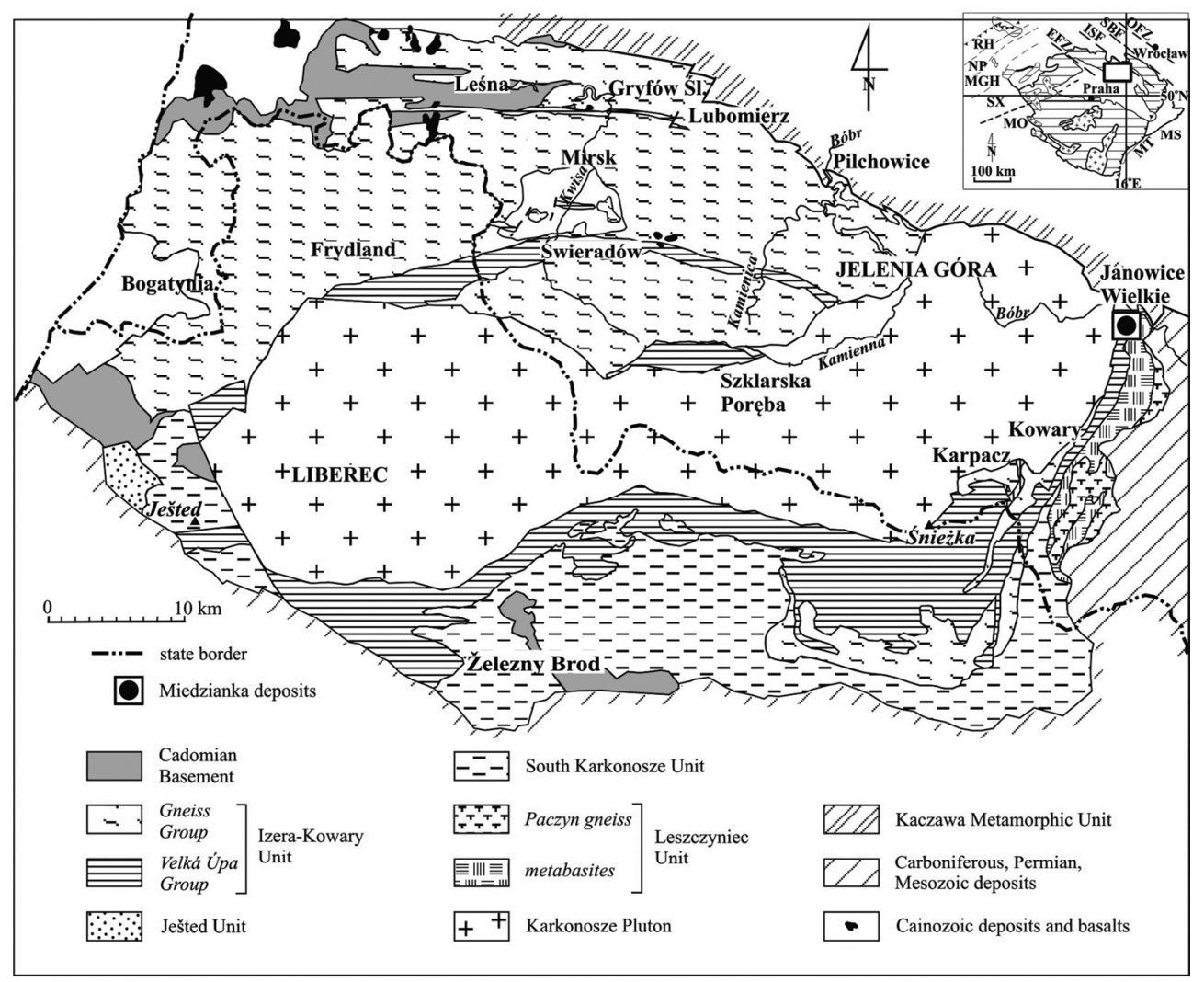

Fig. 1. Geological sketch map of the Karkonosze-Izera Massif (KIM; compiled from Chaloupsky 1989, Mazur 1995, Mazur, Aleksandrowski 2001, Oberc-Dziedzic 2003). Insert map: EFZ - Elbe Fault Zone, ISF - Intra-Sudetic Fault, MGH - Mid-German High, MO - Moldanubian Zone, MS - Moravo-Silesian Zone, NP - Northern Phyllite Zone, OFZ - Odra Fault Zone, RH - Rhenohercynian Zone, SBF - Sudetic Boundary Fault, SX - Saxothuringian Zone, TB - TepláBarrandian Zone. Insert shows the position of the KIM in the Bohemian Massif. 
The mining operations, dating back to the beginning of the XIIth century (Dziekoński 1972), started in various parts of the district between Miedzianka and Ciechanowice. According to Berg (1938 and older references therein), there were four mining fields in operation, namely, the western field close to the Karkonosze granite and the central field (both named collectively as the Miedzianka field), the eastern field in Ciechanowice and the northern field located north of the Bóbr River. The latter field can be identified with the so-called "Lead Mountains" (Góry Ołowiane) which are a part of the Kaczawa Metamorphic Complex. Mineralization encountered in Przybkowice, close to the Ciechanowice mine, belongs spatially to the eastern field (Wojciechowski, Wołkowicz 1985), though the character of this mineralization resembles that of the northern field sensu Berg (1913). The copper, arsenic, lead, zinc, silver, gold and uranium ores were intermittently worked at several small mines (see Dziekoński 1972) with varying success until 1955 when all mines were finally closed and flooded (Zimnoch 1978). Numerous old mine dumps and several old adits still exist in the area. Some of the latter are preserved in excellent condition.

The geology of the Miedzianka district was described in detail by Websky (1853) and Krush (1901), Berg (1913, 1938), Petrascheck (1933a, b), Schneiderhöhn (1941) and others. After World War II, new data on ore minerals from Miedzianka were published by Zimnoch $(1967,1978)$. The uranium mineralization was described in detail by Kaczmarek (1959), unfortunately, only in an unpublished industrial report.

According to Websky (1853), there were three "vein formations" in the Miedzianka district individually characterized by copper, lead and barite. In some cases, the barite veins, being the youngest, showed cross-cutting contacts with the older veins. In the copper vein formation, Websky (1853) identified four vein systems of different strikes, all younger than the Karkonosze granite.

Krusch (1901) found two types of ores: (i) contact-metasomatic, lensoidal oxidesulphide body, including the bornite-dominated "blue deposit" and (ii) hydrothermal veins. The latter include the older, hornblende-chlorite-fluorite veins post-dating the metasomatic bodies, but pre-dating porphyry dykes and the younger, quartz-copper sulphide veins contemporaneous with the Intra-Sudetic Fault. The relationship of the hydrothermal ore veins to the Intra-Sudetic Fault was mentioned also by Berg (1913).

Petrascheck (1933a) described the magnetite deposit with associated pyrite and $\mathrm{Cu}, \mathrm{Zn}$ As, and Fe sulphides. He also observed zonal magnetite crystals which he regarded as proof of contact-metasomatic origin of the ore. Moreover, he related $\mathrm{Cu}$ and $\mathrm{Ba}$ veins to extrusive volcanism younger than the Karkonosze granite intrusion.

Schneiderhöhn (1941) described in detail the ores from the western and eastern fields. In the eastern field, he distinguished three generations of ore and gangue minerals, the first originating from metamorphic processes, and the later two related to hydrothermal ore formation. In the western field, he described, after Krusch (1901), the concordant, contactmetasomatic deposit and the high-temperature, hydrothermal vein-type deposit. He also compiled an instructive geological map of the deposit area.

In the Miedzianka district, the diversified ore-mineral assemblage was found and described, mostly in the XIXth century, by several German authors (e.g. Websky 1851, 1853, 1886, Fiedler 1863, Roth 1867, Traube 1888, Krusch 1901 and others, fide Zimnoch 1967, 1978, Lis and Sylwestrzak 1986 and Mikulski 2007). The assemblage includes, in 
alphabetical order: acanthite, aikinite, antimonite, argentite, arsenopyrite, azurite, bismuthinite, bismutoferrite, bornite, brochantite, carrollite, cassiterite, chalcocite, chalcopyrite, chloanthite, chrysocolla, cobaltite, covellite, cuprite, digenite, electrum, erythrite, eugenite, Fe-hydroxides, galena, gersdorffite, gummite, hematite, ilmenite, linnaeite, löllingite, magnetite, malachite, marcasite, mimetite, native Ag, native As, native $\mathrm{Bi}$, native $\mathrm{Cu}$, nickeline, olivenite, polybasite, proustite, pyrite, pyromorphite, pyrrhotite, rammelsbergite, safflorite, smaltite, rutile, sphalerite, stephanite, stolzite, stromeyerite, tenorite, tetrahedrite, uraninite, uranophane, volborthite, wulfenite and xanthoconite. Some new minerals were added after World War II by Zimnoch (1967, 1976, 1978), namely, galenobismutite, lievrite, luzonite, maghemite, martite, melnikovite, mushketovite and stibioenargite. Moreover, Kaczmarek (1959) mentioned autunite and torbernite. Some new publications, e.g. Pieczka et al. (1988), Holeczek and Janeczek (1991), Ciesielczuk and Bzowski (2003), Ciesielczuk et al. (2004), Siuda and Kruszewski (2006), Siuda et al. (2006, 2010), Siuda and Gołębiowska (2011) and Siuda (2012) provide data on secondary minerals.

The authors identified the minerals mawsonite and wittichenite, previously unknown from the Miedzianka district. They also present new data concerning the geochemistry of known ore minerals, ore structures and the ore-mineral succession.

\section{Materials and methods}

Over 100 polished sections were prepared and examined using a NIKON ore microscope.

The chemical compositions of selected minerals was analyzed with the CAMECA SX 100 microprobe at the Inter-Institute Analytical Complex for Minerals and Synthetic Substances, University of Warsaw, under the following working conditions: acceleration voltage $15 \mathrm{kV}$, beam current $20 \mathrm{nA}$, counting time $20 \mathrm{~s}$ and background time $10 \mathrm{~s}$. The raw results were processed using the PAP software (Pouchou, Pichoir 1985). Elemental analyses employed the following standards, analytical lines and crystals: $\mathrm{S}$ (sphalerite, $\mathrm{K}_{\alpha}$, PET); Ti (rutile, $\left.\mathrm{K}_{\alpha}, \mathrm{PET}\right) ; \mathrm{Cr}\left(\mathrm{Cr}_{2} \mathrm{O}_{3}, \mathrm{~K}_{\alpha}\right.$, PET); $\mathrm{Mn}$ (rhodonite, $\mathrm{K}_{\alpha}, \mathrm{LIF}$ ); Fe (hematite, $\mathrm{K}_{\alpha}$, LIF); Co (Co metal, $\mathrm{K}_{\alpha}$, LIF); $\mathrm{Ni}\left(\mathrm{NiO}, \mathrm{K}_{\alpha}\right.$, LIF); $\mathrm{Cu}$ (chalcopyrite, $\mathrm{K}_{\alpha}$, LIF); Zn (sphalerite, $\left.\mathrm{K}_{\alpha}, \mathrm{LIF}\right)$; As (GaAs, $\left.\mathrm{L}_{\alpha}, \mathrm{TAP}\right)$; Se (ZnSe, $\left.\mathrm{L}_{\alpha}, \mathrm{TAP}\right) ; \mathrm{Nb}\left(\mathrm{LiNbO}_{3}, \mathrm{~L}_{\alpha}, \mathrm{PET}\right)$; Ag (Ag metal, $\left.\mathrm{L}_{\alpha}, \mathrm{PET}\right) ; \mathrm{Cd}\left(\mathrm{CdS}, \mathrm{L}_{\alpha}\right.$, PET); In (InAs, $\left.\mathrm{L}_{\alpha}, \mathrm{PET}\right) ; \mathrm{Sn}$ (cassiterite, $\left.\mathrm{L}_{\alpha}, \mathrm{PET}\right) ; \mathrm{Sb}$ (InSb, $\mathrm{L}_{\alpha}$, PET); Te (PbTe, $\mathrm{L}_{\alpha}$, LIF); Ta (tantalite, $\mathrm{M}_{\alpha}$, TAP); W (scheelite, $\mathrm{M}_{\alpha}$, TAP); Pb (galena, $\mathrm{M}_{\alpha}$, PET); $\mathrm{Bi}\left(\mathrm{Bi}_{2} \mathrm{Te}_{3}, \mathrm{M}_{\alpha}, \mathrm{PET}\right)$.

\section{Geological setting}

The Karkonosze-Izera Massif (KIM, Fig. 1) (Mazur, Aleksandrowski 2001), the largest-scale geological unit in the West Sudetes, SW Poland, is situated at the NE peripheries of the Bohemian Massif. The central part of the KIM is occupied by the Variscan Karkonosze granite, which has been dated between $304 \mathrm{Ma}$ and $328 \mathrm{Ma}$ (Pin et al. 1987; Duthou et al. 1991; Kröner et al. 1994; Machowiak, Armstrong 2007). The boundary between the KIM and the Kaczawa Metamorphic Complex is the Intra-Sudetic Fault. 
The eastern part of the KIM (Fig. 1) comprises two NNE-SSW-elongated metamorphic belts. The western metamorphic belt is composed of rocks belonging to the Czarnów Schist Formation (CSF; Teisseyre 1973) comprising chlorite-albite-muscovite-quartz schists and phyllites with intercalations of marbles, graphitic phyllites, quartzitic schists, quartzofeldspathic rocks and greenschists in its southern part, and albite-mica schists, quartzofeldspathic rocks, and striped amphibolites in its northern part. The eastern metamorphic belt includes metabasites and metagranites accompanied by metasediments represented by pyrite-bearing schists belonging to the meta-igneous Leszczyniec Unit (Kryza, Mazur 1995). The Przybkowice Unit is composed of greenschists and phyllites (Oberc 1961, Teisseyre 1973). All these rocks were metamorphosed and deformed during the Variscan orogeny (Mazur 1995), prior to the emplacement of the Karkonosze granite. At the contact with granite, the CSF rocks were transformed into hornfelses. The metamorphic formations are cut by Late Variscan porphyry dykes (Berg 1913), partly older and partly younger than the ore mineralization. Our study concerns ore mineralization in the Miedzianka district located at the northern termination of the two metamorphic belts, in the neighborhood of the Przybkowice Unit.

\section{The Miedzianka field (Western field)}

Three types of ore mineralization are known from the western mining field. These are (i) metasomatic magnetite ores, (ii) $\mathrm{Cu}$ - bearing hydrothermal veins and (iii) uraniumbearing hematite ores (Zimnoch 1978).

The metasomatic magnetite ores form a lensoidal body about 250-meters long that dips steeply to the northeast. It is concordant with the hosting carbonate- and calc-silicate rocks (Zimnoch 1978). The metasomatic nature of this ore has been earlier recognized by Krusch (1901) and Zimnoch $(1967,1978)$. The main economic-grade mineralization accumulated in hydrothermal veins dominated by copper and/or uranium minerals. The uranium mineralization - primary pitchblende accompanied by several secondary uranium minerals as well as galena, chalcopyrite and pyrite - was discovered in 1950. A detailed description can be found in Kaczmarek (1959).

In the samples collected from the dumps, we found chalcopyrite, pyrite, galena, bornite, chalcocite, digenite, arsenopyrite, magnetite, sphalerite, tetrahedrite-tennantite, bornite, hematite, martite, pyrrhotite, ilmenite, cassiterite and covellite. All are hosted in coarsegrained quartz veins with chlorite that cut the quartz-mica schists.

Ore minerals form irregular, massive accumulations and veinlets as well as disseminated structures. Occasionally, pseudo-layers concordant with the foliation of the host-rocks are evident. The two types of ore were analyzed, namely $\mathrm{Cu}$-sulfide-dominated ore and magnetite-dominated ore.

\subsection{Copper sulphide ore}

In the copper sulphide ores, chalcopyrite is the main ore mineral. It forms intergrowths with bornite (Fig. 2) or pyrite. Chalcocite, digenite and covellite are also present. The observed intergrowths with pyrite form streaks underlining the foliation of the host-rocks. Usually, the sulphide ores also contain some amounts of members of the tetrahedrite- 
tennantite series. Small inclusions of galena and accumulations of idiomorphic arsenopyrite crystals also occur.

Chalcopyrite exhibits a stable chemical composition (Tab. 2): $\mathrm{Fe}$ (28.9-30.1wt\%), $\mathrm{Cu}$ (34.2-35.2wt\%) and $\mathrm{S}(34.8-35.2 \mathrm{wt} \%)$. In a few crystals, increased amounts $(<0.03 \mathrm{wt} \%)$ of Se were detected. Pyrite shows somewhat variable contents of Fe (44.5-47.6wt\%) and S (52.2-54.0wt.\%) and small amounts of $\mathrm{Ni}$ and Co. Two crystals of native Bi contained 98.4 and $99.1 \mathrm{wt} \% \mathrm{Bi}$, and small quantities of $\mathrm{Fe}$.

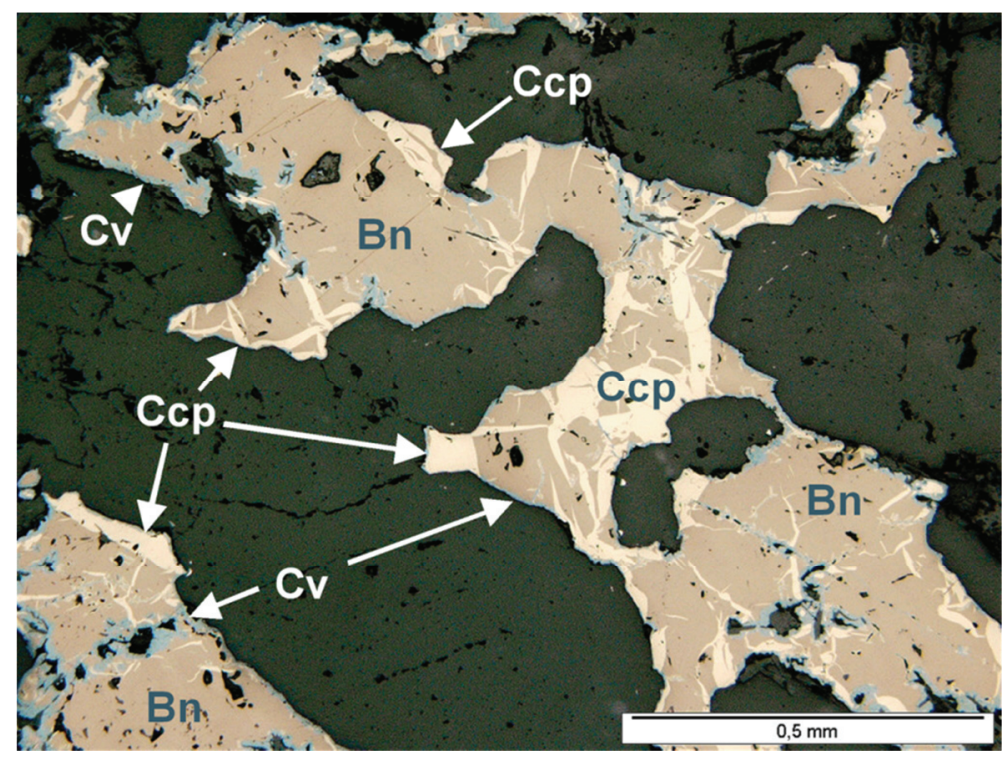

Fig. 2. Irregular accumulation of bornite $(\mathrm{Bn})$ partly replaced by chalcopyrite $(\mathrm{Ccp})$ and covellite $(\mathrm{Cv})$. Miedzianka, sample M-6. Reflected light, 1 polar.

\subsection{Magnetite ore}

The magnetite ore is composed of massive accumulations of coarse (up to several millimeters across) magnetite grains intergrown with sphalerite. Microscopic examination reveals two generations of magnetite. The first generation builds the cores of mineral aggregates and exhibits granular- to rounded shapes. The second generation overgrows the first and can be easily identified under the microscope due to its poor polishing properties (Fig. 3). The outer (external) parts of the aggregates are characterized by idiomorphic, distinctly-zoned, rhomboidal magnetite crystals (Fig. 4).

The BSE images reveal the zonation of the magnetite crystals, earlier described by Zimnoch (1978). In the outer parts of magnetite grains, anisotropic hematite of higher reflectance may be the result of martitization. In some parts, radial hematite (specularite) grows onto magnetite aggregates (Fig. 3). Intergrowths of magnetite with chalcopyrite, pyrite and arsenopyrite were also observed. Small inclusions of cassiterite occur in some magnetite aggregates (Fig. 3). The chemical composition of cassiterite from sample M-11 is shown in Table 1. 
Pyrrhotite forms irregular accumulations with pyrite, scarce pentlandite and with chalcopyrite. Marcasite occurs as a replacement of pyrrhotite in samples dominated by pyrrhotite. This replacement starts from cracks in or at the edges of pyrrhotite aggregates. In many samples, pyrrhotite is almost completely replaced by marcasite and by Fe-hydroxides. The iron sulphides typically show evidence of weathering.

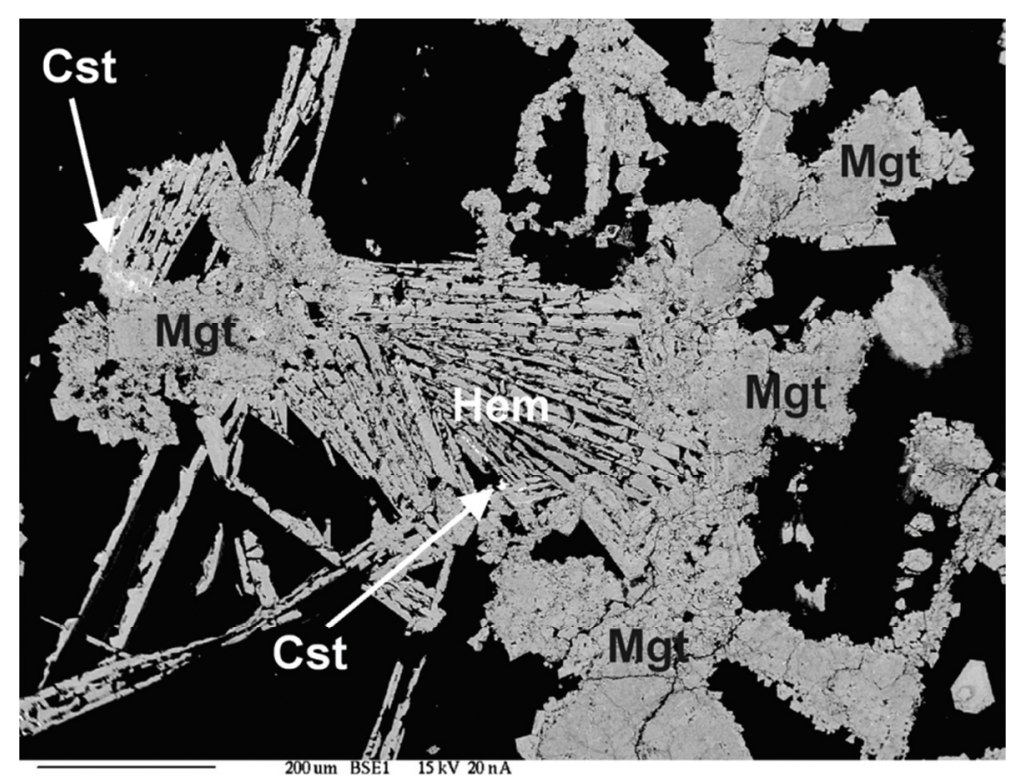

Fig. 3. Irregular accumulation of magnetite (Mgt) and radial specularite (Hem). Two generations of magnetite are visible; older magnetite in the core of aggregates and a younger, hipidiomorphic, magnetite overgrowth. Small inclusions of cassiterite (Cst) are evident. Miedzianka, sample M-11, BSE image.

TABLE 1

Chemical composition of cassiterite from the Miedzianka field analysed by microprobe (average of three measurements).

\begin{tabular}{llll}
\hline Compound & Concentration $(w t \%)$ & Cation & Atom p.f.u. \\
\hline $\mathrm{Fe}_{2} \mathrm{O}_{3}$ & 0.35 & $\mathrm{Fe}$ & 0.0065 \\
$\mathrm{MnO}$ & 0.02 & $\mathrm{Mn}$ & 0.0004 \\
$\mathrm{WO}_{3}$ & 0.00 & $\mathrm{~W}$ & 0.0000 \\
$\mathrm{Nb}_{2} \mathrm{O}_{5}$ & 0.12 & $\mathrm{Nb}$ & 0.0014 \\
$\mathrm{Ta}_{2} \mathrm{O}_{5}$ & 0.00 & $\mathrm{Ta}$ & 0.0000 \\
$\mathrm{TiO}_{2}$ & 2.30 & $\mathrm{Ti}$ & 0.0427 \\
$\mathrm{SnO}_{2}$ & 96.42 & $\mathrm{Sn}$ & 0.9490 \\
Total & 99.21 & & \\
\hline
\end{tabular}




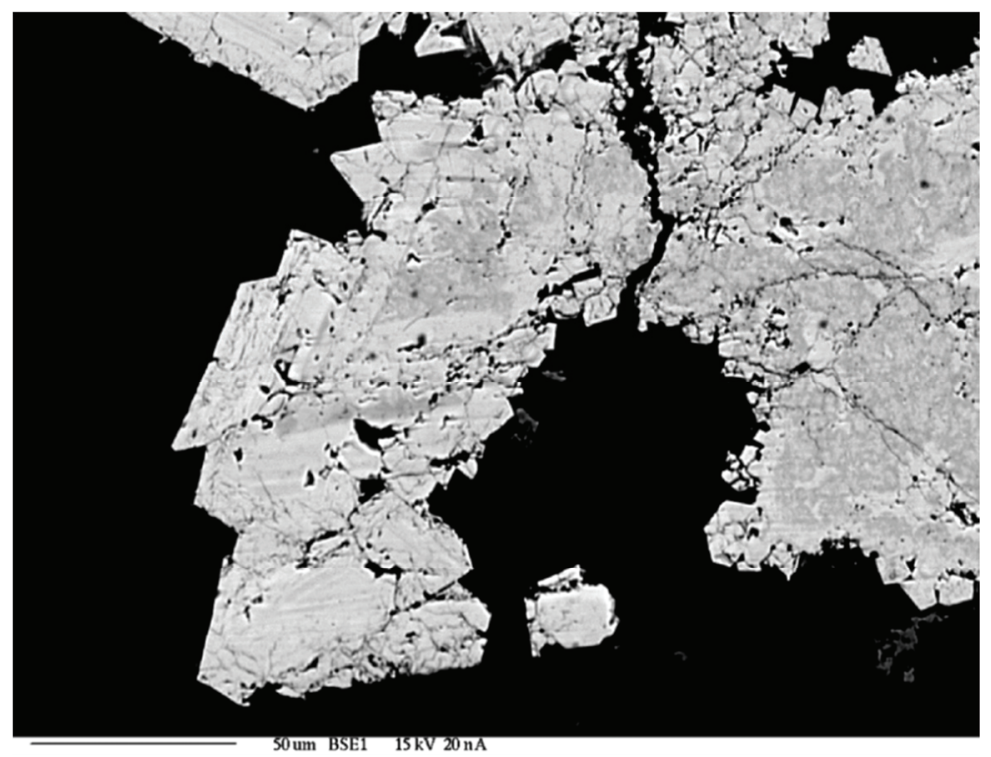

Fig. 4. Nest-like accumulation of hipidiomorphic magnetite crystals (younger generation) with clear growth zoning. Miedzianka, sample M-11. Reflected light, 1 polar.

\section{The Ciechanowice field (Eastern field)}

In the Ciechanowice area, many old mine dumps were re-exploited in recent years, exposing quite fresh, unweathered ore fragments. Microscopic examination enabled identification of a quite diversified assemblage of ore minerals including chalcopyrite, pyrite, sphalerite, galena, tetrahedrite-tennantite, bismuthinite, native $\mathrm{Bi}$, arsenopyrite, löllingite, cassiterite, cobaltite, gersdorffite, chalcocite, cassiterite, bornite, covellite, marcasite, pyrrhotite and rutile. Moreover, microprobe analyses allowed us to identify mawsonite and wittichenite, which had not been found previously in the Ciechanowice ore.

The ore mineralization is hosted mainly in amphibolites in some cases intergrown with quartz and rare carbonates. Dark minerals composing amphibolites are usually strongly chloritized. Minor host rocks are quartz-chlorite schists and quartzites.

The ore minerals form irregular, nest-like accumulations or veinlets, several millimetres thick, together with quartz. Moreover, disseminations concordant with the foliation of the host-rocks also occur.

Chalcopyrite is the main ore mineral except for a few samples in which pyrite predominates. Locally, arsenopyrite or bornite are also present in appreciable quantities. Chalcopyrite forms irregular, nest-like aggregates, over $1 \mathrm{~cm}$ in diameter, scattered in the host-rocks or in quartz veinlets. It is commonly intergrown with sphalerite. Minute chalcopyrite exsolutions in sphalerite are also observed (Fig. 5). Galena, chalcocite and tetrahedrite-tennantite series members are present, as well. In some sections, chalcopyrite forms sieve-structured blasts containing inclusion of rock-forming minerals, mainly quartz. Inclusions of pyrite, cobaltite or members of cobaltite-gersdorffite series are very common (Fig. 5, 6). These are relics after the replacement of previous associations. 
Occasionally, arsenopyrite is replaced by chalcopyrite (Fig. 7) or chalcopyrite forms the matrix of breccia composed of arsenopyrite fragments. The chemical composition of chalcopyrite from Ciechanowice is shown in Table 2.

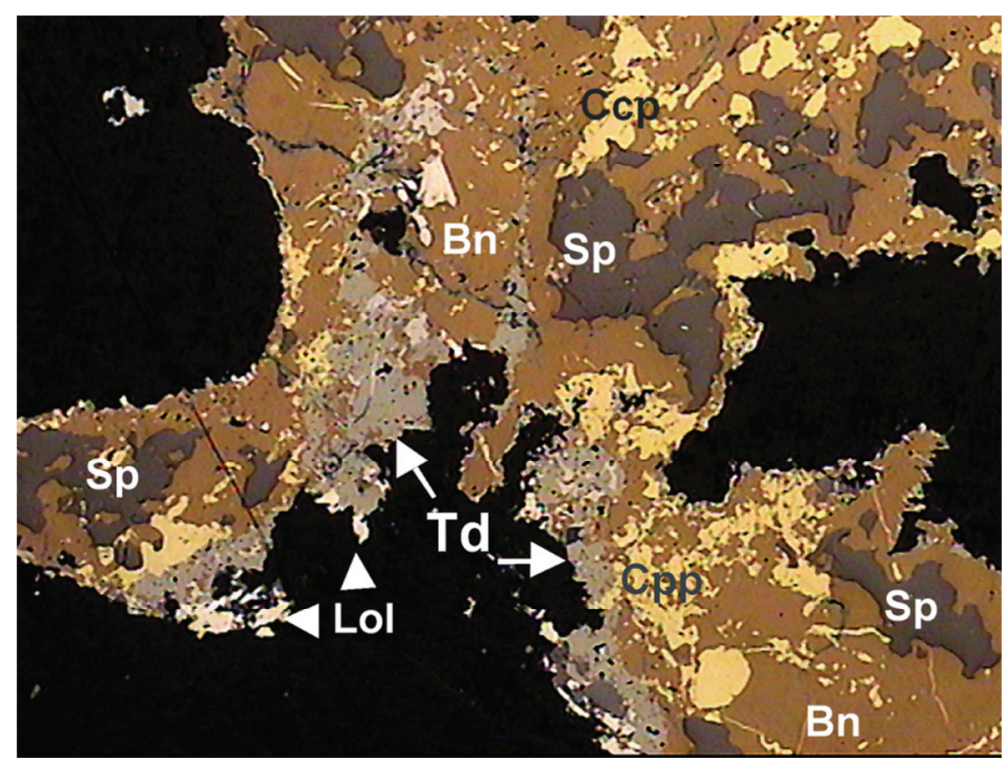

Fig. 5. Aggregates of bornite (Bn), chalcopyrite (Ccp), sphalerite (Sp) and tetrahedrite (Td) with inclusions of löllingite (Lol). Ciechanowice, sample Ciech $97-1$. Reflected light, 1 polar.

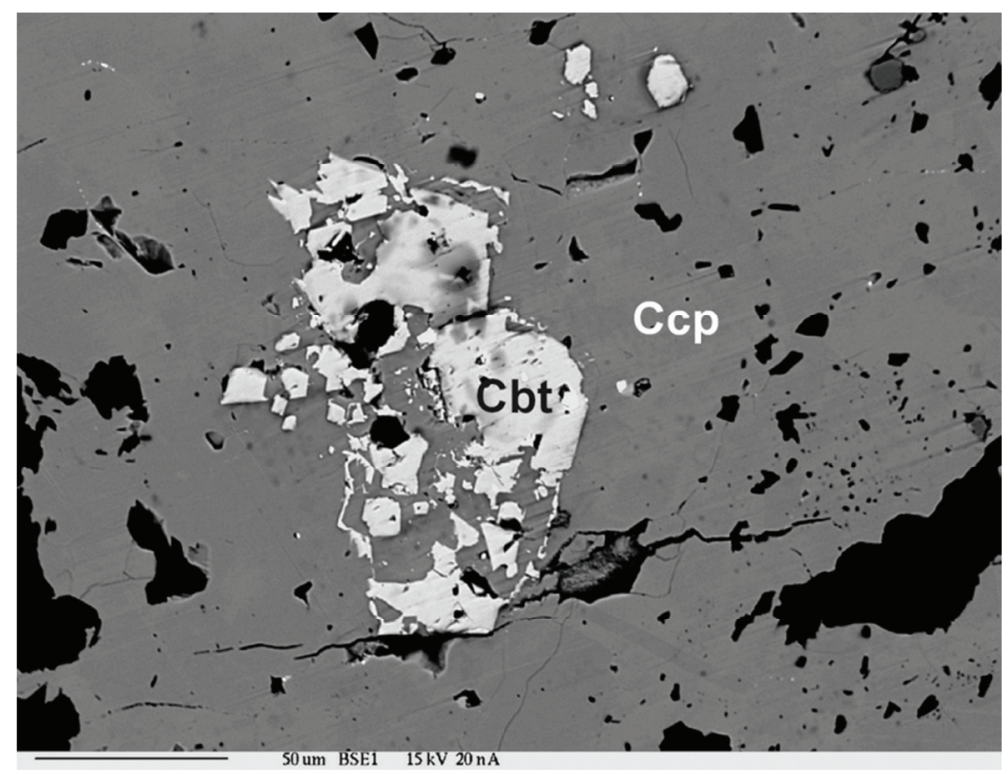

Fig. 6. Chalcopyrite (Ccp) with relics of cobaltite (Cbt) partly replaced by chalcopyrite. Ciechanowice, sample Ciech-2. BSE image. 


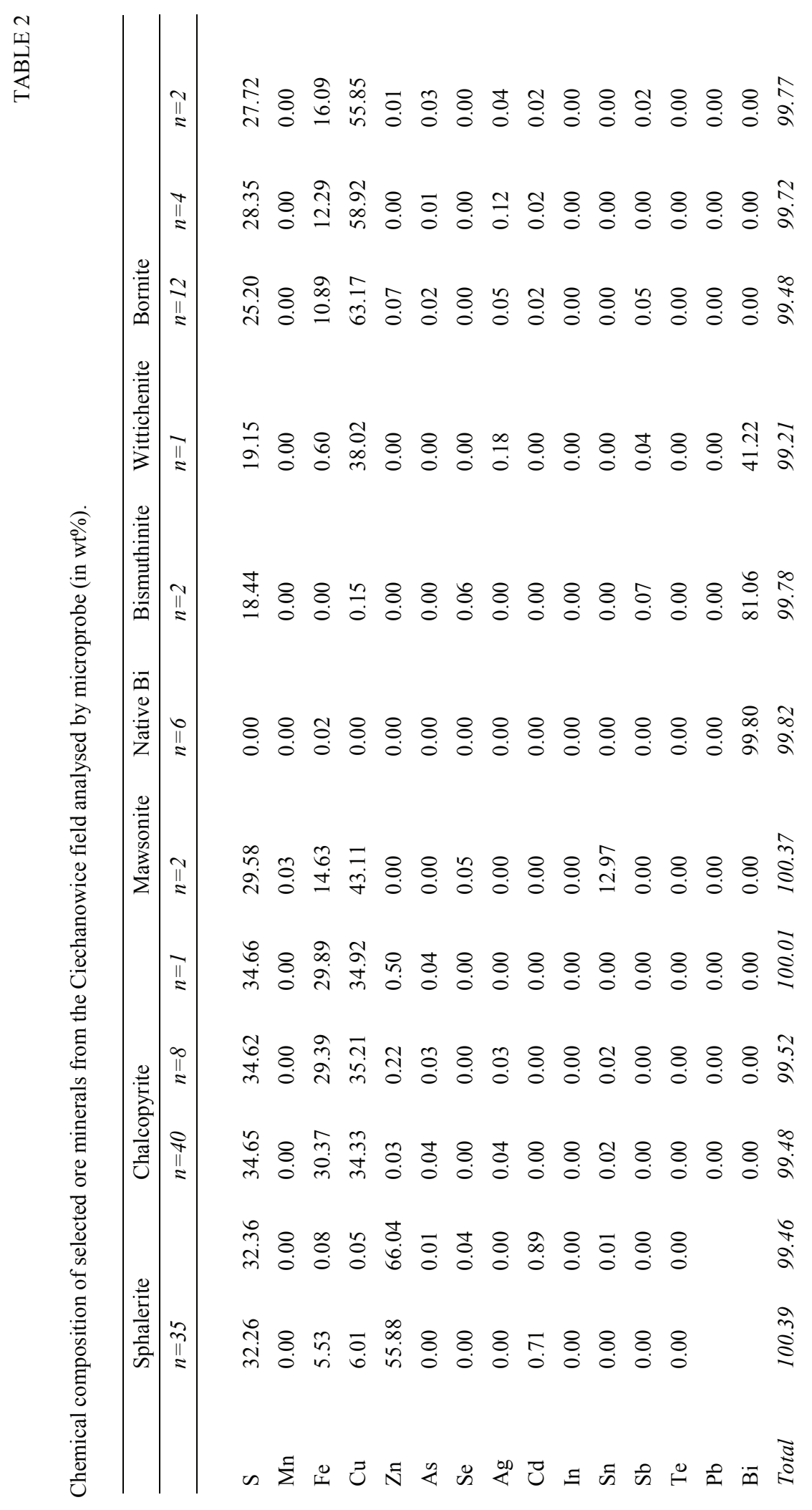




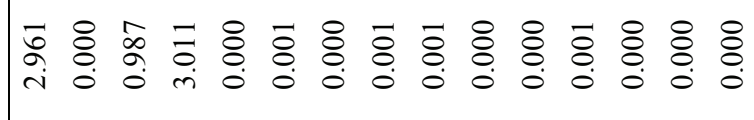

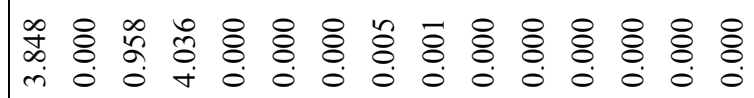

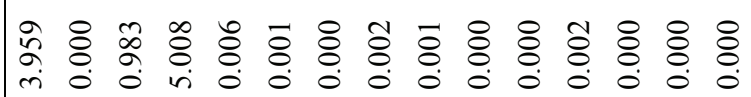

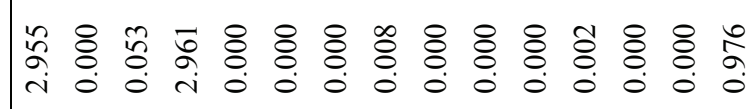

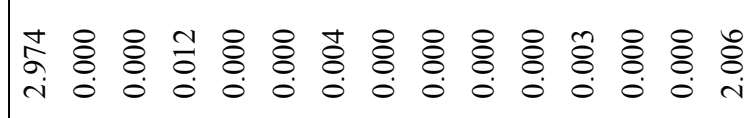

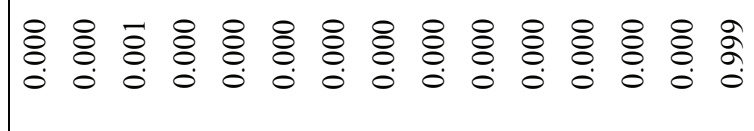

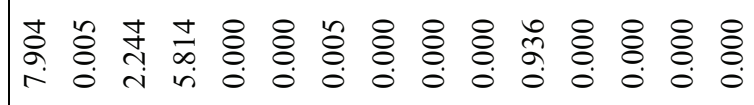

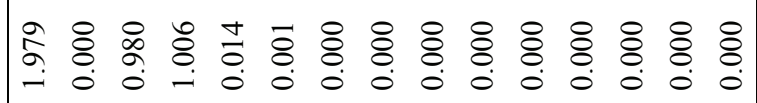

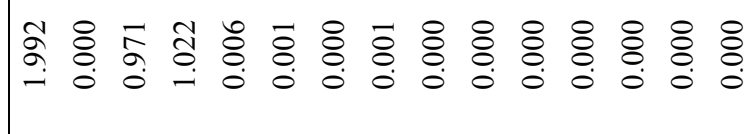

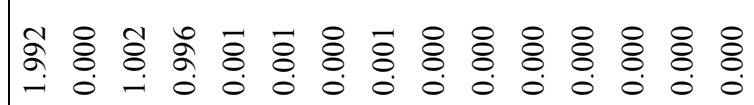

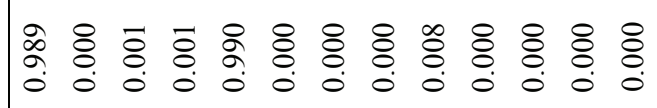

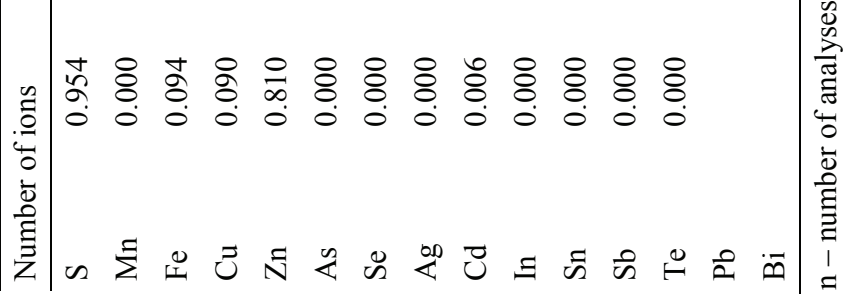


Pyrite occurs in nearly all samples in which chalcopyrite is the main component but, in a few samples, it is the main or only ore mineral. It forms disseminated structures in which the pyrite crystals up to $1 \mathrm{~mm}$ in diameter are distributed along the foliation planes of the host rocks. Pyrite veinlets were also observed with the replacements of pyrite by chalcopyrite.

Some pyrite crystals host small inclusions of chalcopyrite occurring together with sphalerite, galena and safflorite, as well as Ti-minerals and gangues. In some samples, idiomorphic pyrite crystaloblasts form aggregates up to $10 \mathrm{~mm}$ in diameter. The chemical composition of pyrite is given in Table 3. Increased amounts of As (averaging $0.29 \mathrm{wt} \%$ ) are remarkable.

In some samples, intergrowths of marcasite with sphalerite resemble "rib structures". Marcasite is a secondary ore mineral formed at the initial stage of weathering at the mine dumps.

Sphalerite is a common ore mineral seen in almost all samples, mainly as intergrowths with chalcopyrite and bornite (Fig. 5). Most sphalerite crystals contain minute exsolutions of chalcopyrite. The composition of sphalerite is characterized by variable contents of $\mathrm{Fe}$ (0.08-5.53wt \%) and relatively low contents of Cd (0.7-1.7wt\%; Table 2). Thus, two types of $\mathrm{ZnS}$ : with high- and low- Fe can be distinguished.

Galena occurs in the majority of samples but only in minor amounts (Fig. 8). It forms intergrowths with chalcopyrite, sphalerite and Bi minerals. Two types of galena were distinguished based on trace-element composition. The first type contains admixtures of $\mathrm{Ag}$ (ca 0.04-0.81wt\%), Se (0.06-0.51wt\%) and $\mathrm{Bi}(0.0-0.39 \mathrm{wt} \%)$ whereas the second is free of trace elements (Table 4).

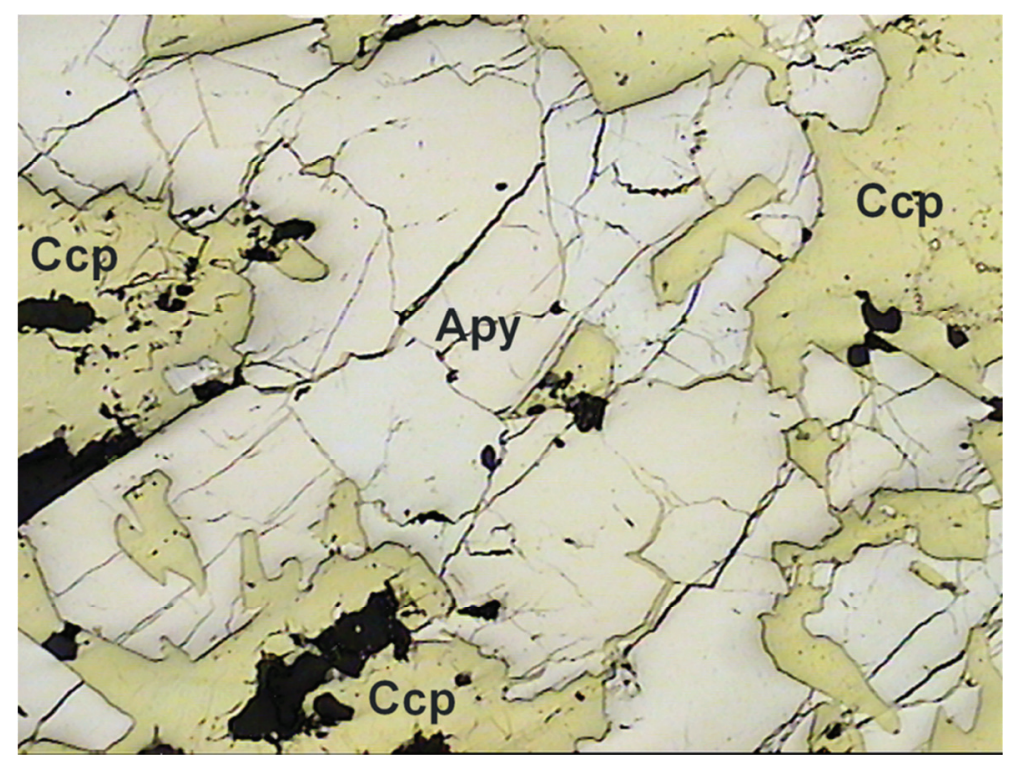

Fig. 7. Arsenopyrite (Apy) crystals partly replaced by chalcopyrite (Ccp). Ciechanowice, sample Ciech-45/1. Reflected light, 1 polar. 


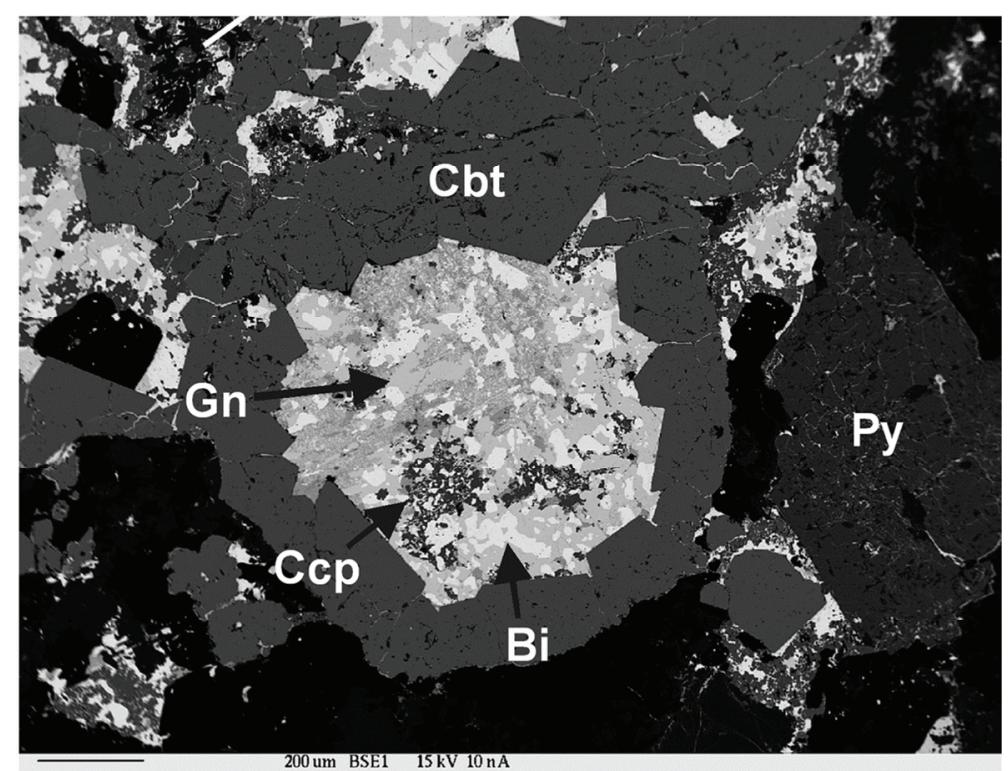

Fig. 8. Spheroidal structure of cobaltite (Cbt), filled with an intergrowth of galena $(\mathrm{Gn})$, chalcopyrite (Ccp) and native bismuth (Bi), accompanied by pyrite (Py). Ciechanowice, sample Ciech-4/45. BSE image.

Members of tetrahedrite-tennantite series are very common and are found in majority of chalcopyrite-dominated polished sections. They form intergrowths with chalcopyrite, galena, sphalerite and native Bi (Fig. 5). Microscopic examination and the microprobe analyses reveal the presence of various members of tetrahedrite-tennantite isomorphic series but tetrahedrite prevails. They are accompanied by intermediate phases containing some admixture of $\mathrm{Bi}$. Contents of $\mathrm{Sb}$ vary from 1.56 to $27.06 \mathrm{wt} \%$ and those of arsenic from 1.31 to $19.50 \mathrm{wt} \%$. The chemical composition of these minerals is shown in Table 5 .

Mawsonite $\left(\mathrm{Cu}_{5.814} \mathrm{Fe}_{2.244} \mathrm{Sn}_{0.936} \mathrm{~S}_{7.904}\right)$ is a rare phase found as inclusions in chalcopyrite. Because of its small crystal size, it was identified mainly by microprobe. It contains up to $15 \mathrm{wt} \% \mathrm{Fe}$ (Table 2).

Native Bi and bismuthinite were recorded in most polished sections but only in small amounts. Native Bi forms tiny aggregates overgrown by chalcocite, bismuthinite and, locally, by pyrite and cobaltite (Fig. 8). Microprobe analyses did not reveal detectable amounts of trace elements (Table 2).

Wittichenite was identified by microprobe analysis (Table 2) in a single sample. It occurs as an inclusion in tennanite accompanied by bornite, chalcopyrite, arsenopyrite, chalcocite and galena.

Bornite usually occurs in small amounts. It was encountered as the main ore mineral only in a single polished section (Fig. 2). It forms intergrowths with chalcopyrite, sphalerite and tetrahedrite. Microprobe analyses reveal variable, in some cases, nonstoichiometric amounts of $\mathrm{Fe}$ (average values from 10.89-16.08wt\%; Table 2). Some grains contained increased amounts of $\mathrm{Ag}$ (ca $0.1 \mathrm{wt} \%$; Table 2).

Chalcocite was rarely observed, always in intergrowths with chalcopyrite. 
Arsenopyrite $\left(\mathrm{Fe}_{0.999} \mathrm{As}_{0.975} \mathrm{~S}_{1.018}\right)$ was observed as a dominating ore mineral in a few polished sections where it formed massive intergrowths with chalcopyrite (Fig. 7), pyrite, sphalerite and native $\mathrm{Bi}$. Individual arsenopyrite crystals are usually idiomorphic and rhomboidal in cross-section. Some arsenopyrite crystals are cracked and the cracks are filled with chalcopyrite.

Members of cobaltite-gersdorffite series $\left(\mathrm{Co}_{0.487-0.915} \mathrm{Ni}_{0.006-0.315} \mathrm{As}_{0.893-1.009} \mathrm{~S}_{0.989-1.108}\right)$ occur as tiny, idiomorphic inclusions of pink color and high reflectivity in chalcopyrite. Microprobe analyses revealed both the cobaltite end-member and the minerals of intermediate compositions (Table 3). Rare spheroidal aggregates of cobaltite-gersdorffite were also seen with pyrite, chalcopyrite, native Bi, galena and chalcocite (Fig. 8).

Löllingite is a rare mineral. Its microscopic identification is difficult due to its minute crystal size. It was identified as intergrowths with bornite accompanied by tetrahedritetennantite members (Fig. 5).

Pyrrhotite was found only in two polished sections. It forms disseminated crystals or irregular intergrowths with pyrite, sphalerite and galena.

Rutile is a common component of amphibolites from the Miedzianka district. Usually, it forms rod-like structures with individual crystals parallel to the foliation of host-rock. Accumulations of rutile crystals also occur in chalcopyrite. In its chemical composition, $\mathrm{SiO}_{2}(<0.6 \mathrm{wt} \%), \mathrm{V}_{2} \mathrm{O}_{5}(0.6-0.7 \mathrm{wt} \%), \mathrm{Nb}_{2} \mathrm{O}_{3}(0.1-0.2 \mathrm{wt} \%)$ and some $\mathrm{FeO}(0.2-0.3 \mathrm{wt} \%)$ were detected. A rare variety of rutile forming idiomorphic crystals with polygonal crosssections contains $\mathrm{SiO}_{2}(0.06-0.2 \mathrm{wt} \%), \mathrm{Nb}_{2} \mathrm{O}_{3}(0.2-0.5 \mathrm{wt} \%$.) and $\mathrm{FeO}$ (ca $0.3-1.0 \mathrm{wt} \%$ ). Locally, this rutile variety hosts tiny crystals of cassiterite which seem to be formed contemporaneously with $\mathrm{TiO}_{2}$ (Fig. 9).

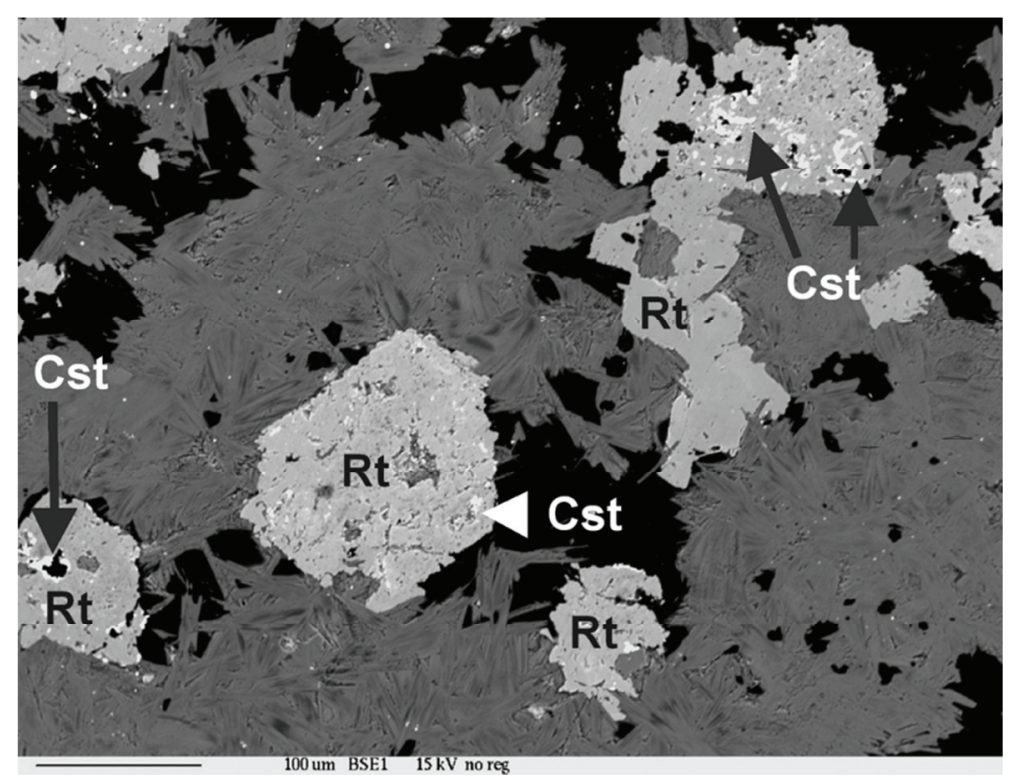

Fig. 9. Hipidiomorphic crystals of rutile (Rt) with tiny inclusions of cassiterite (Cst) in chlorite (grey). Ciechanowice, sample Ciech-112, BSE image. 


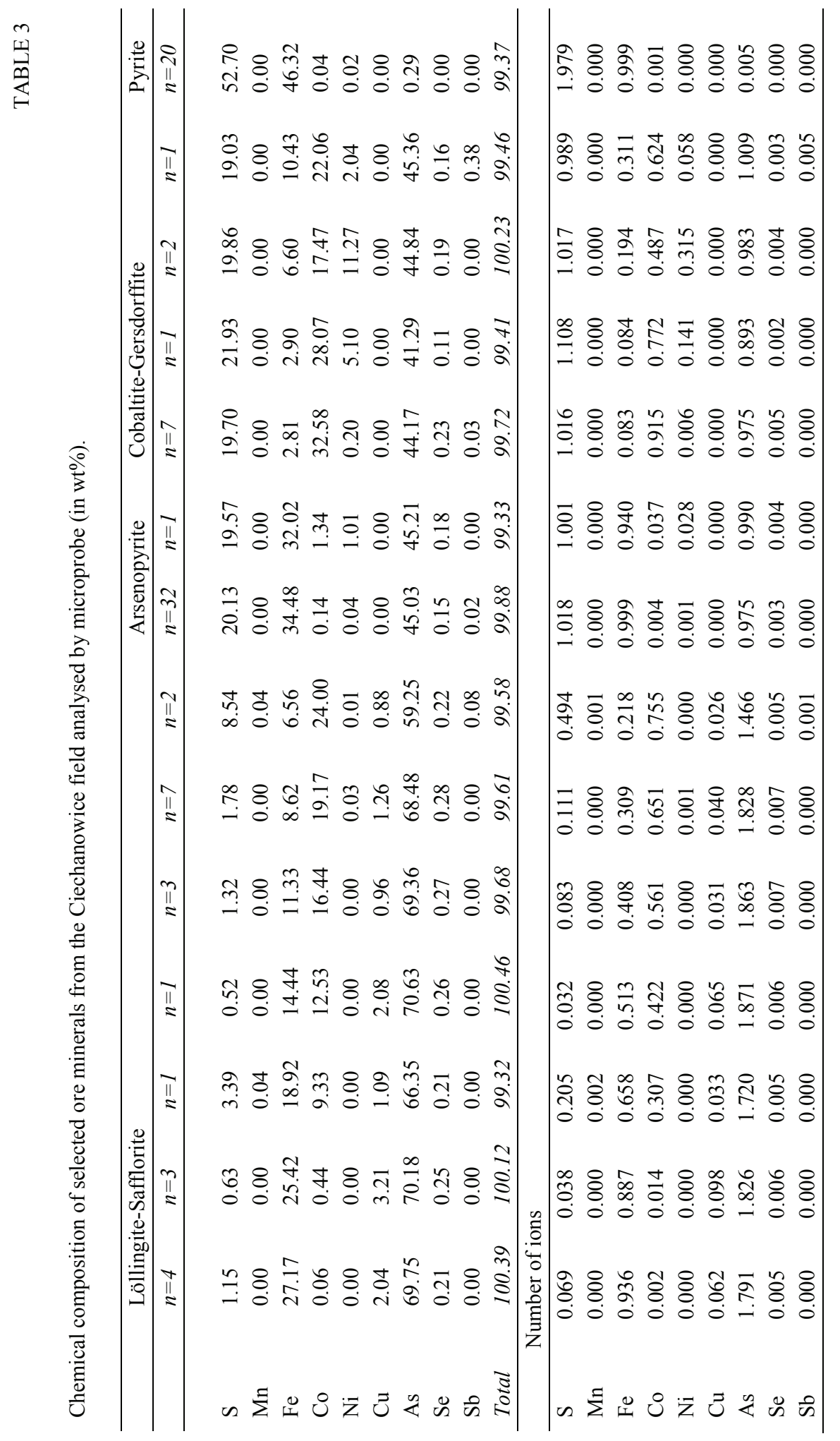


TABLE 4

Chemical composition of galena from the Ciechanowice area analysed by microprobe (in wt $\%$ ).

\begin{tabular}{|c|c|c|}
\hline & \multicolumn{2}{|c|}{ Galena } \\
\hline & $n=3$ & $n=22$ \\
\hline S & 13.07 & 13.29 \\
\hline $\mathrm{Mn}$ & 0.00 & 0.00 \\
\hline $\mathrm{Fe}$ & 0.05 & 0.04 \\
\hline $\mathrm{Cu}$ & 0.00 & 0.00 \\
\hline $\mathrm{Zn}$ & 0.00 & 0.00 \\
\hline As & 0.00 & 0.00 \\
\hline $\mathrm{Se}$ & 0.51 & 0.06 \\
\hline $\mathrm{Ag}$ & 0.72 & 0.01 \\
\hline $\mathrm{Cd}$ & 0.05 & 0.07 \\
\hline In & 0.00 & 0.00 \\
\hline $\mathrm{Sn}$ & 0.00 & 0.00 \\
\hline $\mathrm{Sb}$ & 0.02 & 0.01 \\
\hline $\mathrm{Te}$ & 0.11 & 0.00 \\
\hline $\mathrm{Pb}$ & 84.73 & 86.64 \\
\hline $\mathrm{Bi}$ & 0.27 & 0.00 \\
\hline \multirow[t]{2}{*}{ Total } & 99.54 & 101.12 \\
\hline & \multicolumn{2}{|c|}{ Number of ions } \\
\hline $\mathrm{S}$ & 0.974 & 0.987 \\
\hline $\mathrm{Mn}$ & 0.000 & 0.000 \\
\hline $\mathrm{Fe}$ & 0.002 & 0.002 \\
\hline $\mathrm{Cu}$ & 0.000 & 0.000 \\
\hline $\mathrm{Zn}$ & 0.000 & 0.000 \\
\hline As & 0.000 & 0.000 \\
\hline $\mathrm{Se}$ & 0.016 & 0.002 \\
\hline $\mathrm{Ag}$ & 0.016 & 0.000 \\
\hline $\mathrm{Cd}$ & 0.001 & 0.002 \\
\hline In & 0.000 & 0.000 \\
\hline Sn & 0.000 & 0.000 \\
\hline $\mathrm{Sb}$ & 0.000 & 0.000 \\
\hline $\mathrm{Te}$ & 0.002 & 0.000 \\
\hline $\mathrm{Pb}$ & 0.978 & 0.996 \\
\hline $\mathrm{Bi}$ & 0.003 & 0.000 \\
\hline
\end{tabular}

$n$ - number of analyses

Covellite occurs as traces in the vicinity of $\mathrm{Cu}$ minerals. It is the product of early-stage weathering. 
TABLE 5

Chemical composition of tetrahedrite-tennantite series members from the Ciechanowice field analysed by microprobe (in $\mathrm{wt} \%$ ).

\begin{tabular}{|c|c|c|c|c|c|}
\hline & \multicolumn{5}{|c|}{ Tetrahedrite-Tennantite series } \\
\hline & $n=3$ & $n=2$ & $n=50$ & & $n=2$ \\
\hline S & 23.85 & 24.24 & 24.41 & 26.48 & 27.56 \\
\hline $\mathrm{Mn}$ & 0.03 & 0.01 & 0.00 & 0.00 & 0.00 \\
\hline $\mathrm{Fe}$ & 1.31 & 1.46 & 1.00 & 1.13 & 1.95 \\
\hline $\mathrm{Cu}$ & 37.82 & 38.49 & 38.76 & 41.11 & 43.77 \\
\hline $\mathrm{Zn}$ & 6.75 & 6.45 & 6.91 & 7.13 & 5.37 \\
\hline As & 1.31 & 3.59 & 4.13 & 13.95 & 19.50 \\
\hline $\mathrm{Se}$ & 0.03 & 0.02 & 0.04 & 0.07 & 0.07 \\
\hline $\mathrm{Ag}$ & 0.12 & 0.11 & 0.21 & 0.10 & 0.07 \\
\hline $\mathrm{Cd}$ & 0.18 & 0.14 & 0.05 & 0.26 & 0.34 \\
\hline In & 0.00 & 0.00 & 0.00 & 0.00 & 0.00 \\
\hline $\mathrm{Sn}$ & 0.13 & 0.10 & 0.12 & 0.00 & 0.00 \\
\hline $\mathrm{Sb}$ & 27.06 & 23.41 & 21.68 & 9.09 & 1.56 \\
\hline $\mathrm{Te}$ & 0.01 & 0.00 & 0.00 & 0.00 & 0.05 \\
\hline $\mathrm{Pb}$ & 0.00 & 0.00 & 0.00 & 0.00 & 0.00 \\
\hline $\mathrm{Bi}$ & 1.28 & 1.75 & 2.74 & 0.00 & 0.00 \\
\hline Total & 99.87 & 99.78 & 100.05 & 99.33 & 100.25 \\
\hline \multicolumn{6}{|c|}{ Number of ions } \\
\hline $\mathrm{S}$ & 12.099 & 12.168 & 12.361 & 12.661 & 12.572 \\
\hline $\mathrm{Mn}$ & 0.009 & 0.004 & 0.000 & 0.000 & 0.000 \\
\hline $\mathrm{Fe}$ & 0.381 & 0.422 & 0.290 & 0.311 & 0.512 \\
\hline $\mathrm{Cu}$ & 9.682 & 9.749 & 9.905 & 9.918 & 10.075 \\
\hline $\mathrm{Zn}$ & 1.679 & 1.587 & 1.717 & 1.671 & 1.201 \\
\hline As & 0.284 & 0.771 & 0.896 & 2.855 & 3.807 \\
\hline $\mathrm{Se}$ & 0.005 & 0.005 & 0.008 & 0.013 & 0.013 \\
\hline $\mathrm{Ag}$ & 0.018 & 0.016 & 0.031 & 0.014 & 0.010 \\
\hline $\mathrm{Cd}$ & 0.026 & 0.021 & 0.008 & 0.035 & 0.044 \\
\hline In & 0.000 & 0.000 & 0.000 & 0.000 & 0.000 \\
\hline $\mathrm{Sn}$ & 0.018 & 0.014 & 0.016 & 0.000 & 0.000 \\
\hline $\mathrm{Sb}$ & 3.615 & 3.094 & 2.891 & 1.145 & 0.188 \\
\hline $\mathrm{Te}$ & 0.002 & 0.000 & 0.000 & 0.000 & 0.005 \\
\hline $\mathrm{Pb}$ & 0.000 & 0.000 & 0.000 & 0.000 & 0.000 \\
\hline $\mathrm{Bi}$ & 0.099 & 0.135 & 0.213 & 0.000 & 0.000 \\
\hline
\end{tabular}

\section{The Przybkowice area}

In the Przybkowice area, Wojciechowski and Wołkowicz (1985) described a quartzbarite vein with minor sulphides including chalcopyrite, chalcocite, bornite, covellite, 
members of tetrahedrite-tennantite series and galena. The sulphides are replaced by the secondary minerals: cerussite, malachite and Fe-hydroxides.

The vein found by the present authors in the bed of an unnamed stream presumably corresponds to that described by Wojciechowski and Wołkowicz (1985) although it strikes $\mathrm{N} 36 \mathrm{~W}$ and dips at $70^{\circ}$ to the southwest. The vein cuts metasomatically-altered greenschists. The gangues are several generations of quartz cut by barite veinlets and enclosing barite nests.

Microscopic examinations of polished sections revealed ore minerals identified earlier by Wojciechowski and Wołkowicz (1985), i.e. chalcopyrite, chalcocite, digenite, pyrite and galena. All suphides form disseminated grains and aggregates in quartz and barite. Some aggregates may reach up to $5 \mathrm{~cm}$ in diameter.

Chalcopyrite, the dominant ore mineral, occurs as disseminated crystals or aggregates containing inclusions of pyrite. Chalcopyrite aggregates frequently show bluish marginal zones composed of digenite and covellite. These sulphides also fill cracks within chalcopyrite. Chalcopyrite crystals show near-stoichiometric compositions.

Chalcocite and digenite usually form intergrowths with chalcopyrite or occur as tiny, disseminated, single crystals. Microprobe analyses reveal compositions with increased amounts of $\mathrm{Fe}$ (ca $2.4 \mathrm{wt} \%$ ).

Galena occurs as individual crystals or large aggregates (up to a few millimeters across) of isometric grains. These are replaced by cerussite at the margins.

TABLE 6

Ore-mineral succession in the Miedzianka disctrict with formation temperatures of selected minerals.

rutile
magnetite
cassiterite
pyrrhotite
arsenopyrite
löllingite-safflorite
cobaltite-gersdorffite
pyrite
sphalerite
chalcopyrite
chalcocite
tetrahedrite-tennantite
native Bi, bismuthinite
mawsonite
bornite
galena

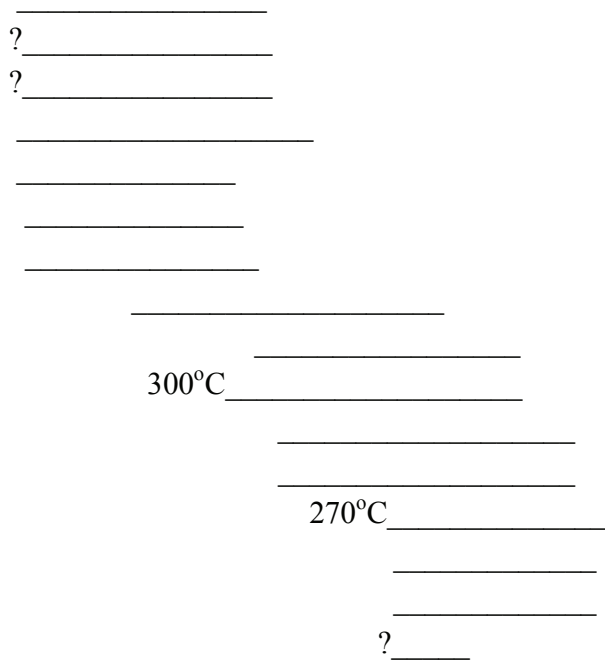




\section{Discussion}

\subsection{Ore-mineral succession}

Microscopic observations led to the crystallization sequence of the ore minerals to be. It was supported by some microporobe analyses enabling geothermometric evaluations.

Rutile, magnetite and cassiterite are the oldest ore minerals; they crystallized at an early, oxide-ore forming stage, before prior to sulphides and suphosalts. All of the oxides occur in complex intergrowths, e.g. cassiterite with rutile in the Ciechanowice field and with magnetite in the Miedzianka field. Cassiterite presumably crystallized under reducing conditions with $\mathrm{Ti}$ transported in the form of $\mathrm{Ti}^{3+}$-complexes, as suggested by common, relatively high admixtures of $\mathrm{Ti}\left(<2.3 \mathrm{wt} \% \mathrm{TiO}_{2}\right.$; Table 1$)$.

The earliest, non-oxide components of ore are pyrrhotite encountered mainly in the Miedzianka western field, in the close vicinity of the Karkonosze granite, and löllingite accompanied by Co-löllingite, Fe-safflorite, arsenopyrite and cobaltite in the Ciechanowice field. Arsenopyrite that crystallized after the $\mathrm{Fe}$ - and Co-arsenides very rarely shows enrichment $(>1.0 \mathrm{wt} \%$ ) in Co and Ni. Usually, contents of these elements are negligible. The crystallization sequence löllingite $\rightarrow$ Co-löllingite $\rightarrow$ Fe-safflorite $\rightarrow$ arsenopyrite $\rightarrow$ cobaltite suggests that during the early, sulfo-arsenide mineralization stage, ore minerals crystallized from fluids of high As activity with both the arsenides and sulfoarsenides stable. Increasing $\mathrm{S}$ contents from the older, Fe- to the younger, Co-arsenides corroborates falling As contents in the ore-forming fluids during this early stage of mineralization. Nickel is rather subordinate. It is absent from both the Fe- and Co-arsenides, concentrating only in arsenopyrite $(<1.0 \mathrm{wt} \%)$ and in cobaltite $(<11.3 \mathrm{wt} \%)$. The average contents of As (32.50(72)at\%) and $\mathrm{S}(33.94(80) \mathrm{at} \%)$ point to the significance of $\mathrm{S} \rightarrow$ As substitution in arsenopyrite at progressively decreasing temperatures. The coexistence of arsenopyrite with arsenides suggests that crystallization had commenced under conditions of löllingite stability and had progressed towards the crystallization of arsenopyrite with pyrrhotite until the crossing of pyrrhotite/pyrite equilibrium.

The replacement of arsenopyrite by chalcopyrite, the infilling of open spaces between euhedral cobaltite crystals by chalcopyrite and the replacement of cobaltite by chalcopyrite indicate that chalcopyrite crystallized after the arsenides-arsenopyrite-cobaltite assemblage.

The intergrowths of sphalerite and chalcopyrite, and chalcopyrite inclusions in sphalerite argue for the simultaneous formation of both minerals. Relatively low $\mathrm{Fe}$ contents in sphalerite in comparison with those of $\mathrm{Cu}$ show that the sphalerite-chalcopyrite pair crystallized after crossing the pyrrhotite/pyrite equilibrium, i.e. under the conditions of pyrite stability, as a sphalerite-chalcopyrite solid-solution. The decrease in both $\mathrm{Fe}$ and $\mathrm{Cu}$ contents in sphalerite (up to almost pure $\mathrm{ZnS}$ ) may reflect the crystallization of sphalerite at relatively low temperatures. On the other hand, chalcopyrite commonly contains small $(<0.50 \mathrm{wt} \% \max )$ amounts of $\mathrm{Zn}$ which may indicate, as Scott (1983) concluded, that chalcopyrite crystallized from hydrothermal solutions of significant $\mathrm{Zn}$ activity at temperatures somewhat above $300^{\circ} \mathrm{C}$. A similar temperature was determined by Siuda (2012) from sphalerite exsolutions in chalcopyrite. However, commonly-observed much lower $\mathrm{Zn}$ contents in chalcopyrite $(0.20 \mathrm{wt} \%$ to complete absence) may indicate even lower crystallization temperatures. 
Minerals of the tetrahedrite-tennantite series represent an almost complete solid solution. Generally, these phases correspond to Zn-bearing varieties, in some cases enriched in $\mathrm{Cd}$. Tetrahedrite contains low $\mathrm{Bi}, \mathrm{Ag}$ and $\mathrm{Sn}$, documenting the enrichment of the hydrothermal solutions in these elements during the later stages of ore formation. Mawsonite probably formed at this stage, as well.

Galena occurs in two varieties. The first, probably higher-temperature phase, is enriched in $\mathrm{Ag}(<0.6-0.8 \mathrm{wt} \%)$, and in $\mathrm{Se}(0.06-0.51 \mathrm{wt} \%)$ and $\mathrm{Bi}(0.00-0.27 \mathrm{wt} \%)$. The second probably more common variety does not contain these elements.

Native $\mathrm{Bi}$ crystallized at ca $270^{\circ} \mathrm{C}$, probably together with bismuthinite. A similar formation temperature for Bi minerals was determined by Siuda (2012).

Bornite crystallization at low temperatures is a result of the reaction $\mathrm{Chp} \rightarrow \mathrm{Bn}+\mathrm{Py}$. Bornite varieties with higher $\mathrm{Fe}$ contents and of compositions close to $\mathrm{Cu}_{4} \mathrm{FeS}_{<4}$ are probably the products of bornite transformations into chalcocite-group minerals.

In conclusion, the succession of ore minerals established here is generally consistent with that proposed by Petrascheck (1933a). The main difference concerns cassiterite; this mineral belongs with the oldest ore minerals in the Miedzianka district.

The vein at Przybkowice is located in a marginal zone of the Miedzianka district, in host rocks belonging to the Leszczyniec Unit. Hence, it should be related rather to the northern mining field, as suggested by Berg (1913).

\subsection{Metallogenetic implications}

The ore deposits of the Miedzianka mining district show similarities to those of the Kowary district. In both areas, older, lensoidal magnetite accumulations are followed by younger veins with polymetallic-uranium mineralization.

Differences between the Miedzianka and the Kowary ore districts concern the origin of magnetite. The Miedzianka magnetite deposit has been interpreted as contact-metasomatic, genetically related to the Karkonosze granite, whereas the Kowary magnetite deposit resembles rather the metamorphosed Lahn-Dill type (see discussion in Zimnoch 1967, 1978).

The hydrothermal, vein-type polymetallic mineralization is known from both the Miedzianka and the Kowary districts, and from other sites in the eastern metamorphic envelope of the Karkonosze granite. The authors agree with the concept of Petrascheck (1933b and references therein) who proposed a genetic relationship of this mineralization to the Karkonosze granite. The granite intrusion seems to have been the source of both the thermal energy and, at least partly, the hydrothermal solutions responsible for the formation of the Miedzianka, Kowary and other ore deposits in the eastern envelope of the intrusion. It has been suggested that quartz-sulphide veins in the Wieściszowice pyrite deposit also belong to this hydrothermal system (Oberc-Dziedzic et al. 2011).

It is interesting to note that Kanasiewicz and Sylwestrzak (1970) linked the distribution of deposits in the northern part of the Bohemian Massif (including the Sudetes) to deep tectonic zones which may have been the pathways of hydrothermal ore solutions. This concept was discussed in detail by Michniewicz (2003).

The isotopic age of ore mineralization in the Miedzianka area is still unknown. However, it may referred to $\mathrm{Pb} / \mathrm{U}$ ages of pitchblende from Kowary (265 and $70 \mathrm{Ma}$; Lis et 
al. 1971) and $\mathrm{Pb} / \mathrm{Pb}$ galena model ages from Czarnów (250 and 210 Ma; Legierski 1973), indicating the Variscan provenance of ore-forming solutions.

\section{Conclusions}

Our new data supplement existing knowledge of the ore mineralization of the Miedzianka district, especially its chemistry and the conditions of its formation.

1. Mawsonite and wittichenite are identified for the first time in the Ciechanowice field (Eastern field).

2. The geochemistry of ore minerals is examined in detail.

3. the changes in the composition of the hydrothermal ore-forming fluids are defined. An early, Ti, Fe and Sn-rich system evolved through a succession of systems characterized, in turn, by $\mathrm{Fe}-\mathrm{As}-\mathrm{S}, \mathrm{Fe}-\mathrm{Co}-\mathrm{As}-\mathrm{S}, \mathrm{Cu}-\mathrm{Zn}-\mathrm{S}$ and, finally, $\mathrm{Cu}-\mathrm{Pb}-\mathrm{Sb}-\mathrm{As}-\mathrm{Bi}$.

4. The well-known ore succession is supplemented by formation temperatures for some minerals resulting from geochemical considerations, namely, chalcopyrite (slightly over $300^{\circ} \mathrm{C}$ ) and native $\mathrm{Bi}\left(\mathrm{ca} 270^{\circ} \mathrm{C}\right)$.

Acknowledgements. Thanks are due to Dr. P. Dzierżanowski and Ms. L. Jeżak from Warsaw University for their kind assistance with the microprobe analyses. The project was financed by the Polish Committee for Scientific Research, grant No. 5 T12B 036 25. The authors are very much indebted to anonymous reviewers for valuable remarks and corrections.

\section{References}

Berg, G. (1913). Die Erzlagerstätten der nördlischen Sudeten (pp. 1-47). Festschrift zum XII Allgemeinen Deutschen Bergmannstage. Breslau.

Berg, G. (1938). Geologische Karte von Preussen und benachbarten deutschen Ländern. Erläuterungen zu Blatt Kupferberg. II Auflage. Preussischen geologischen Landesanstalt, Lieferung 193. Berlin, 1-61.

Chaloupský, J. (1989). Geological evolution of the Krkonoše-Jizerské hory crystalline complex in the Precambrian and Early Paleozoic. In J. Chaloupský (ed.) Geologie Krkonoš a Jizerských hor. (pp. 1-288). Praha: Ústředni ústav geologický.

Ciesielczuk, J., \& Bzowski, Z. (2003). Secondary (Cu, Zn)-oxyminerals from the Miedzianka copper deposit in Rudawy Janowickie, Sudetes Mts. Preliminary report. Mineralogia Polonica Special Papers, 17, 150-152.

Ciesielczuk, J., Szeęeg, E., Kuźniarski, M., \& Bylina, P. (2004). Preliminary data of erythrite from Ciechanowice (Miedzianka deposit, Sudetes Mts.). Mineralogia Polonica Special Papers 24, 123126.

Duthou, J.L., Couturie, J.P., Mierzejewski, M.P., \& Pin, C. (1991). Oznaczenia wieku granitu Karkonoszy metodą izochronową, rubidowo-strontową, na podstawie całych próbek skalnych. [Next dating of granite sample from the Karkonosze Mountains using Rb-Sr total rock isochrone method]. Przeglad Geologiczny, 36, $75-79$ (in Polish, English summary).

Dziekoński, T. (1972). Wydobywanie i metalurgia kruszców na Dolnym Ślasku od XIII do połowy XX wieku. [Ore mining and metallurgy in the Lower Silesia from the XIIIth to the half of the XXth centuries]. (pp. 1-420). Wrocław: Ossolineum (in Polish). 
Holeczek, J., \& Janeczek, J. (1991). Pseudomalachite from Radzimowice and some comments on its occurrence in Miedzianka (Sudetes Mts.). Mineralogia Polonica, 22, 17-25.

Hoehne, K. (1934). Quantitativ chemische und erzmikroskopische Bestimmung von Arsen, Antimon, Zinn und Wismut in vorwiegend schlesischen Bleiglanzen. Chemie der Erde, 2, 219-268.

Kaczmarek, L. (1959). Uranonośność Sudetów. Granit i jego wschodnia osłona. [Uranium potential of the Sudety Mts. Granite and its eastern envelope]. Unpublished industrial report of the R1 Enterprise (in Polish).

Kanasiewicz, L., \& Sylwestrzak, H. (1970). Zależność między przebiegiem głębokich stref tektonicznych a rozmieszczeniem złóż endogenicznych w Sudetach. [Relations between the course of deep tectonic zones and distribution of endogenous deposits in Sudetes]. Przeglad Geologiczny, 18, 219-221.

Kröner, A., Hegner, E., Hammer, J., Haase, G., Bielicki, K-H., Krauss, M., \& Eidam, J. (1994). Geochronology and Nd-Sm systematics of Lusatian granitoids: significance for the evolution of the Variscan orogen in eastcentral Europe. Geologische Rundschau, 83, 357-376.

Kryza, R., \& Mazur, S. (1995). Contrasting metamorphic paths in the SE part of the Karkonosze-Izera Block (Western Sudetes, SW Poland). Neues Jahrbuch für Mineralogie, Abhandlungen, 169, 157192.

Krusch, P. (1901). Über die Klassifikation der Erzlagerstätten bei Kupferberg in Schlesien. Zeitschrift der deutschen geologischen Gesellschaft, 52, 216-228.

Legierski, J. (1973). Model ages and isotopic composition of ore leads of Bohemian Massif. Časopis proMineralogii a Geologii, 18, 1-23.

Lis, F.J., Kosztolanyi, Ch., \& Coppens, R. (1971). Étude géochronologique du gisement polymétallique de Kowary (Pologne). Mineralium Deposita, 6, 95-102.

Lis, J., \& Sylwestrzak, H. (1986). Mineraty Dolnego Ślaska [Minerals of the Lower Silesia]. (pp. 1791). Warszawa: Wydawnictwa Geologiczne (in Polish).

Machowiak, K., \& Armstrong, R. (2007). SHRIMP U-Pb zircon age from the Karkonosze granite. Mineralogia Polonica Special Papers, 31, 193-196.

Mazur, S. (1995). Strukturalna i metamorficzna ewolucja wschodniej okrywy granitu Karkonoszy w południowej części Rudaw Janowickich i Grzbiecie Lasockim. [Structural and metamorphic evolution of the country rocks at the eastern contact of the Karkonosze granite in the southern Rudawy Janowickie Mts and Lasocki Range]. Geologia Sudetica, 29, 31-98 (in Polish, English summary).

Mazur, S., \& Aleksandrowski, P. (2001). The Tepla(?)/Saxothuringian suture in the Karkonosze-Izera Massif, Western Sudetes, Central European Variscides. International Journal of Earth Sciences, 90, 341-360.

Michniewicz, M. (2003). Surowce metaliczne w strukturze Bloku Karkonosko-Izerskiego. [Metalliferous deposits in the Karkonosze-Izera Block] (pp. 155-169). In W. Ciężkowski, J. Wojewoda \& A. Żelaźniewicz (Eds.) Sudety Zachodnie: od wendu do czwartorzędu. Wrocław: WIND (in Polish, English summary).

Mikulski, S.Z. (2007). Gold in arsenic ore from the Miedzianka copper Deposit (Rudawy Janowickie Mountains). Mineralogia Polonica Special Papers, 31, 215-218.

Oberc, J. (1961). An outline of the geology of the Karkonosze-Izera Block. Zeszyty Naukowe Uniwersytetu Wrocławskiego, Seria B/8, 139-170.

Oberc-Dziedzic, T. (2003). Granity izerskie: próba odtworzenia przeddeformacyjnej historii [The Izera granites: an attempt of the reconstruction of predeformational history] (pp. 41-52). In W. Ciężkowski, J. Wojewoda \& A. Żelaźniewicz (Eds.) Sudety Zachodnie: od wendu do czwartorzędu. Wrocław: WIND (in Polish, English summary).

Oberc-Dziedzic, T., Mochnacka, K., Mayer, W., Pieczka A., Creaser, R.A., \& Góralski M. (2011). Studies on magnetite and pyrite mineralization, and on their Early Palaeozoic ocean-floor host- 
rocks from the Leszczyniec Unit (West Sudetes, Poland). Annales Societatis Geologorum Poloniae, 81, 133-160

Petrascheck, W.E. (1933a). Die Erzlagerstätten des Schlesischen Gebirges. Archiv für Lagerstättenforschung, 59, 5-51.

Petrascheck, W.E. (1933b). Die Vererzung der Sudeten. Mitteilungen der geologischen Gesellschaft, 24, 191-206.

Pieczka, A., Pieczonka, J., \& Piestrzyński, A. (1988). Minerals of the weathering zone of Miedzianka polymetallic deposit, Rudawy Janowickie (Lower Silesia, Poland). Mineralogia Polonica, 19, 7598.

Pin, C., Mierzejewski, M.P., \& Duthou, J.L. (1987). Wiek izochronowy Rb/Sr granitu karkonoskiego z kamieniołomu Szklarska Poręba Huta oraz oznaczenie stosunku inicjalnego 87Sr/86Sr w tymże granicie. [Isochronous age $\mathrm{Rb} / \mathrm{Sr}$ of Karkonosze granite from the quarry Szklarska Poręba Huta and significance of initial $87 \mathrm{Sr} / 86 \mathrm{Sr}$ in this granite]. Przeglad Geologiczny, 35, 512-517 (in Polish, English summary).

Pouchou, J.L., \& Pichoir, F. (1985). PAP correction procedure for improved microanalysis (pp, 104106). In: J.T. Armstrong (Ed.) Microbeam Analysis. San Francisco: San Francisco Press.

Schneiderhöhn, H. (1941). Lehrbuch der Erzlagerstättenkunde. Bd. 1, Die Lagerstätten der magmatischen Abfolge. Abschnitt 167. Hypoabyssische Gänge und Ruschelzonen mit Kupfererzen in metamorphosierten basischen Gesteinen ("Chloritische Kupferformation") (pp. 442-446). Jena: Gustav Fischer Verlag.

Scott, S.D. (1983). Chemical behaviour of sphalerite and arsenopyrite in hydrothermal and metasomatic environments. Mineralogical Magazine, 47, 427-435.

Siuda, R. (2012). Minerały srebra z kopalni Friederike Juliane w Ciechanowicach (Sudety)

[Silver minerals from the Friederike Juliane mine at Ciechanowice (Sudety Mts, Poland)]. Biuletyn Państwowego

Instytutu Geologicznego, 448, 315-324 (in Polish, English summary).

Siuda, R., Domańska-Siuda, J., \& Gołębiowska, B. (2010). Secondary uranium minerals from the Miedzianka-Ciechanowice deposit (Rudawy Janowickie Mts., Poland). Mineralogia Special Papers, 37, 107-108.

Siuda, R., Gál-Sólymos, K., \& Kruszewski, Ł. (2006). Agardite-(La)-duftite and scorodite-köttigitelike mineral paragenesis from supergenic zone of the Miedzianka deposit (Rudawy Janowickie Mts., Poland) - preliminary report. Mineralogia Polonica Special Papers, 29, 192-194.

Siuda, R., \& Gołębiowska, B. (2008). Mottramite a $\mathrm{Cu}-\mathrm{Pb}$ vanadate from the MiedziankaCiechanowice polymetallic deposit (Rudawy Janowickie Mts, Poland). Mineralogia Polonica Special Papers, 32, 141.

Siuda, R., \& Gołębiowska, B. (2011). Nowe dane o minerałach wietrzeniowych złoża MiedziankaCiechanowice w Rudawach Janowickich (Dolny Śląsk, Polska) [New data on supergene minerals from Miedzianka-Ciechanowice deposit in the Rudawy Janowickie Mountains, (Lower Silesia, Poland)]. Przegląd Geologiczny, 59, 226- 234 (in Polish, English summary).

Siuda, R., \& Kruszewski, L. (2006). New data on bayldonite cornwallite, olivenite and philipsburgite from Miedzianka (Rudawy Janowickie Mts., Sudetes, Poland. Mineralogia Polonica Special Papers, 28, 202-204.

Siuda, R., Kruszewski, Ł., \& Gołębiowska, B. (2010). New data on some silver and mercury minerals from Miedzianka-Ciechanowice deposit (Rudawy Janowickie Mts. Western Sudetes, Poland) preliminary report. Mineralogia Special Papers, 37, 107.

Teisseyre, J.H. (1973). Skały metamorficzne Rudaw Janowickich i Grzbietu Lasockiego. [Metamorphic rocks of the Rudawy Janowickie and Lasocki Range]. Geologia Sudetica, 8, 7-120 (in Polish, English summary).

Websky, M. 1853. Über die geognostischen Verhältnisse der Erzlagerstätten von Kupferberg und Rudolstadt in Schlesien. Zeitschrift der deutschen geologischen Gesellschaft, 5, 373-438. 
Wojciechowski, A. \& Wołkowicz, S. (1985). Czy nowa żyła w okolicach Miedzianki na Dolnym Śląsku? [A new vein in the vicinities of Miedzianka (Lower Silesia)]. Przegląd Geologiczny, 33, 518-519 (in Polish, English summary).

Zimnoch, E. (1967). Zmetamorfizowane złoża rud żelaza w Sudetach na tle innych złóż tego typu [Gîtes métamorphisés des minerais de fer dans les Sudètes comparés au point de vue de structure aux autres gisement analogues]. Geologia Sudetica, 3, 251-296 (in Polish, French summary).

Zimnoch, E. (1976). Occurrence of magnetite in the Miedzianka deposit (Lower Silesia). Bulletin de l'Academie Polonaise des Sciences, 26, 133-138.

Zimnoch, E. (1978). Mineralizacja kruszcowa złoża Miedzianka w Sudetach. [Ore mineralization in the Miedzianka deposit in the Sudetes]. Biuletyn Instytutu Geologicznego, 308, 91-121 (in Polish, English summary). 